\title{
Pengaruh Covid-19 Terhadap Perekonomian Di Negara Asean
}

\author{
Azzahra Aulia Dewi ${ }^{1}$,Darlin Aulia ${ }^{2}$, Kurnia Indah Sumunar ${ }^{3}$, Erni Hernawati ${ }^{4}$, \\ ${ }^{1,2,3,4}$ Sekolah Tinggi Media Nusantara Citra
}

\begin{tabular}{l}
\hline \hline Article Info \\
\hline Article history: \\
Received 20 Juli 2021 \\
Accepted 31 Juli 2021 \\
\end{tabular}

Keywords:

Covid-19, Ekonomi ASEAN

\begin{abstract}
Penelitian ini bertujuan untuk menguji pengaruh covid-19 terhadap perekonomian di negara ASEAN. Metode yang digunakan dalam penelitian ini adalah metode kualitatif dengan menggunakan data sekunder berupa jurnal ilmiah dan studi literatur lainnya. Berdasarkan hasil penelitian, penulis dapat menyimpulkan bahwa dampak dari pandemi virus corona tidak hanya pada sektor kesehatan, tetapi semua sektor juga merasakan dampaknya. Salah satunya, sektor ekonomi dan bisnis. Pertumbuhan ekonomi global dipastikan mengalami kelambatan, termasuk negara yang bergabung dengan ASEAN. Beberapa negara yang bergabung dengan ASEAN harus mengalami resesi saat pandemi virus corona. Hal tersebut terjadi karena adanya kebijakan pemerintah disetiap negara yang mengharuskan masyarakat tidak membuat kerumunan dan mengurangi aktivitas di luar rumah yang menyebabkan proses perekonomian pun terhambat. Kebijakan tersebut dibuat agar penyebaran virus corona dapat teratasi dan pandemi cepat berakhir sehingga semua bisa melakukan aktivitas normal seperti dahulu.
\end{abstract}

This is an open access article under the Lisensi Creative Commons Atribusi-BerbagiSerupa 4.0 Internasional



\section{Corresponding Author:}

Sekolah Tinggi Media Nusantara Citra (STIE MNC)

Email: azzahra.aulia1992@gmail.com

\section{PENDAHULUAN}

Covid-19 tidak hanya berdampak pada bidang kesehatan tetapi sangat mempengaruhi semua aspek dalam bidang kehidupan salah satunya bidang ekonomi. Kinerja ekonomi global pun berkurang karena berkurangnya aktivitas masyarakat. Semua negara termasuk negara yang bergabung di ASEAN merasakan dampaknya. Sudah ada beberapa negara yang mengalami penurunan ekonomi yang sangat drastis kerena wabah Covid-19 yang sudah menyebar hampir 1 tahun ini. Selain itu, topik ini layak dijadikan penelitian, karna topik ini sedang hangat-hangatnya pada saat ini dan dapat menambah informasi untuk pembaca bagaimana kondisi ekonomi saat ini.

Sudah ada beberapa penelitian yang terlebih dahulu melakukan penelitian, salah satunya penelitian yang membahas "Dampak Covid-19 Terhadap Perekonomian Indonesia." Hasil penelitian dari Hanoantubun (2020) menunjukan dampak Covid-19, yaitu kesusahan dalam mencari lapangan pekerjaan, susah untuk memenuhi kebutuhan hidup sehari-hari dan juga tidak mempunyai penghasilan dalam memenuhi kebutuhan, serta kesusahan dari semua sektor bidang juga merasakan dampak Covid19. Saat pandemi seperti ini sistem perekonomian di indonesia tidak berjalan dengan baik karena pemerintah melakukan kebijakan Social Distancing untuk mengurangi penyebaran virus corona. Beberapa kebijakan Social Distancing yaitu, bekerja dari rumah atau WFH (Work From Home) dan PJJ (Pembelajaran Jarak Jauh). Karena sistem perekonomian di Indonesia tidak berjalan dengan baik, banyak karyawan yang di PHK karena kondisi perusahaan yang tidak stabil, sehingga angka pengangguran di Indonesia meningkat menjadi 6,17\%-6,65\% pada Maret 2020, dan masyarakat sulit mencari lapangan 
pekerjaan serta meningkatnya angka kriminal yang terjadi karena sulitnya memenuhi kebutuhan hidup sehari-hari sehingga mereka melakukan tindakan kriminal.

Selain itu, penelitian terdahulu dari Budiyanti (2020) yang membahas "Dampak Virus Corona Terhadap Sektor Perdagangan dan Pariwisata Indonesia" yang menjelaskan perekonomian China mengalami penurunan akibat dari beberapa perusahaan yang harus tutup selama pandemi virus corona. China merupakan negara dengan perekonomian terbesar kedua di dunia dan China adalah rekan dagang utama Indonesia, sehingga jika perekonomian China mengalami penurunan akan berpengaruh kepada perdagangan dunia termasuk Indonesia yang berkerja sama dalam perdagangan dengan China. Dampak dari pandemi virus corona yang paling berpengaruh selain sektor kesehatan terjadi pada sektor perdagangan dan pariwisata. Sepanjang Januari 2020, ekspor dan impor dari dan ke China mengalami penurunan. Jumlah wisatawan dari China di Indonesia juga berkurang sangat drastis. Dan penelitian terdahulu dari Pramisti (2020) yang membahas "Dampak Virus Corona pada Ekonomi, Sri Mulyani : Timbulkan Pesimisme" yang berisi, Menteri Keuangan Sri Mulyani Indrawati mengatakan, pandemi virus Corona telah memunculkan pesimisme terhadap pertumbuhan ekonomi dunia. "Pada 2020 ada harapan untuk menaikan pertumbuhan ekonomi namun hanya dalam waktu seminggu itu berbalik. Pada kondisi pandemi virus Corona ini menimbulkan pesimisme atau melunturnya harapan untuk menaiki pertumbuhan ekonomi pada tahun 2020 ini." Sri Mulyani mengatakan sebenarnya 2020 berpotensi menjadi tahun pengembalian pertumbuhan ekonomi setelah pada tahun 2019 yang belum optimal.

Penelitian yang akan penulis buat akan berbeda dari penelitian sebelumnya. Perbedaannya, ruang lingkup yang akan penulis buat penelitian lebih besar yaitu negara yang bergabung dengan ASEAN tidak hanya Indonesia. Selain itu, penelitian penulis akan mencatumkan data dalam bentuk diagram atau tabel tentang pertumbuhan ekonomi di negara ASEAN. Serta, penelitian penulis akan membahas lebih mendalam atau lebih terperinci dari penelitian sebelumnya. Penulis akan membahas mulai dari awal mula Covid-19, faktor menurunnya perekonomian, dan kondisi perekonomian saat ini serta memberikan saran untuk masyarakat untuk menentukan langkah yang akan diambil dalam menjalani kondisi saat ini.

\section{METODE PENELITIAN}

Metode penelitian yang digunakan oleh penulis adalah studi literatur. Penelitian dengan studi literatur yaitu dengan mengumpulkan data melalui pustaka tertentu, lalu membaca dan mencatat, serta mengolah bahan penelitian dari pustaka yang sudah dibaca. Studi literatur merupakan cara untuk menyelesaikan penelitian dengan mencari referensi dari teori yang berkaitan dengan topik penelitian. Referensi dapat dicari dari buku, artikel, jurnal dan penelitian sebelumnya. Referensi dari teori yang didapatkan dengan cara studi literatur dijadikan sebagai bahan acuan atau fondasi dasar dalam penulisan penelitian.

\section{HASIL PENELITIAN DAN PEMBAHASAN}

\subsection{Hasil dan Pembahasan Penelitian}

\subsubsection{Pertumbuhan Ekonomi pada Negara ASEAN setelah adanya Covid-19.}

Dampak dari wabah virus corona tidak hanya merugikan sektor kesehatan, tetapi semua sektor salah satunya dalam sektor ekonomi. Kelajuan pertumbuhan ekonomi global dipastikan melambat, karena dampak dari wabah virus corona mempengaruhi dunia bisnis. Kegiatan ekspor dan impor pun mengalami penghambatan selama pandemi virus corona. Karena terhambatnya ekspor dan impor kegiatan produksi pun jadi terhambat, bahan baku yang berasal dari luar negeri yang menjadi penyebab kegiatan produksi terhambat. Selain itu, dampak dari wabah virus corona berimbas pada investasi. Minat investasi menurun dengan signifikan, sehingga pertumbuhan investasi juga menurun. Investor yang sudah menanamkan modalnya pun menjadi terhambat untuk merealisasikan investasinya. Berikut ini kondisi pertumbuhan ekonomi di negara yang bergabung dengan ASEAN, antara lain:

1. Indonesia 
Penyebaran virus corona yang cepat di Indonesia membuat pemerintah memberlakukan kebijakan social distancing. Pemerintah membuat dan memberlakukan kebijakan untuk seluruh masyarakat sebagai usaha ke jalan yang lebih baik, yaitu mengurangi korban yang terinfeksi covid-19.(Joharudin, dkk. 2020) Kebijakan pemerintah yang melarang masyarakat menimbulkan kerumuan, membuat aktivitas perekonomian nyaris terhenti. Seperti sekolah ditutup, kantor ditutup, proses jual beli hanya dibolehkan untuk yang menjual kebutuhan sehari-hari, event tertunda, pariwisata ditutup, dan lainnya membuat perputaran ekonomi melambat.(Sari, dkk. 2021) Karena kebijakan pemerintah tersebut juga membuat beberapa perusahaan mengurangi jumlah karyawan yang menyebabkan tingkat pengganguran meningkat dan banyak usaha-usaha yang akhirnya tutup karena mengalami kerugian karena usahanya tidak berjalan dengan baik. Akibat dari banyaknya usaha-usaha yang tutup dan pengurangan karyawan, perekonomian rumah tangga juga berdampak mengalami kesulitan. Adanya bantuan sosial dari pemerintah sangat membantu masyarak tetapi bantuan tersebut belum dapat memaksimalkan peningkatan perekonomian rumah tangga.(Sina, 2020) Menurut Badan Pusat Statistik (2020), telah mencatat laju pertumbuhan ekonomi pada kuartal I (Januari Maret) 2020 hanya tumbuh 2,97\%. Angka ini melambat dari 4,97\% pada kuartal IV 2019. Bahkan kuartal I 2019 mencapai 5,07\% berbeda jauh dengan angka kuartal I 2020. Pada kuartal II Tahun 2020 laju pertumbuhan ekonomi Indonesia mencapai $-5,32 \%$. Angka itu sangat berbanding terbalik dengan kuartal II 2019 yang mencapai 5,05\%. Dan pada kuartal III tahun 2020 laju pertumbuhan ekonomi masih mencapai minus, yaitu $-3,49 \%$ yang berarti Indonesia mengalami resesi. Dampak nyata yang akan dirasakan masyarakat dari menurunnya pertumbuhan ekonomi, yaitu penurunan pendapatan masyarakat secara signifikan dan bertambahnya angka pengangguran karena terjadinya pemutusan hubungan kerja (PHK) secara massal atau banyaknya karyawan yang dirumahkan tanpa diberi gaji dan tunjanggan. Belum 1 tahun wabah virus corona menyebar di Indonesia tetapi sudah memberi dampak yang sangat berpengaruh di semua sektor, termasuk sektor ekonomi. Kebijakan yang diberlakukan di Indonesia dinilai belum efektif sehingga penambahan kasus virus corona masih terus bertambah. Kurang sadarnya masyarakat terhadap protokol kesehatan merupakan salah satu faktor utamanya. Banyak masyarakat yang masih beraktivitas di luar rumah dengan tidak mengikuti protokol kesehatan menjadi keresahannya. Akhirnya pemerintah dengan dibantu pemerintah daerah dan kepolisian melakukan langkah-langkah represif dengan memberikan sanksi pidana bagi masyarakat yang masih melakukan aktivitas di luar rumah dengan tidak mengikuti protokol kesehatan dan berkumpul di tempat-tempat umum.(Setyawati, 2020)

2. Singapura

Singapura merupakan negara yang memiliki kasus positif corona yang besar. Sektor perekonomian Singapura juga mengalami dampak dari wabah virus corona. Kebijakan circuit breaker yang diberlakukan di Singapura merupakan imbauan untuk masyarakat tetap dirumah. Singapura juga telah menutup akses perbatasan untuk pengunjung yang ingin ke Singapura.(Yazid dan Jovita, 2020) Karakteristik perekonomian Singapura yang mengandalkan perdagangan luar negeri dan keuangan internasional yang mempengaruhi penurunan laju perekonomian Singapura. Pihak kementrian Singapura menilai beberapa sektor yang sangat berpengaruh bagi penurunan laju perekonomian di Singapura, seperti transportasi, penjualan grosir, manufaktur, pariwisata, dan permintaan domestik karena masyarakat memutuskan mengurangi aktivitas.(Sari, dkk. 2021) Pada kuartal I 2020 singapura sudah mengalami penurunan mencapai angka -0,7\%. Pada kuartal II 2020 Singapura mengumumkan resesi karena laju ekonomi menurun mencapai -42,9\%. Dan pada kuartal III 2020 Singapura belum bisa keluar dari zona resesi karena laju ekonomi masih mencapai -5,8\%. Dampak dari terjadinya resesi di Singapura, yaitu menurunnya jumlah pekerjaan di Singapura menjadi dampak yang sudah dirasakan dari awal pandemi virus corona sehingga banyaknya karyawan 
yang di PHK membuat angka pengganguran di Singapura meningkat. Pemerintah Singapura memutuskan untuk memberikan suntikan dana yang besar untuk menstabilkan perekonomian Singapura.

3. Malaysia

Malaysia mengalami penurunan laju perekonomian selama wabah virus corona ini. Laju perekonomian Malaysia mengalami perlambatkan karena melakukan kebijakan lockdown yang membuat kegiatan perekonomian terhenti. Pemerintah Malaysia memutuskan untuk menyuntikan dana yang besar, dan menjanjika bahwa $1 / 3$ dana tersebut untuk mendukung sektor bisnis. Namun, perekonomian Malaysia belum bisa berjalan dengan baik karena ada faktor internal, yaitu adanya pergantian pemerintahan beberapa bulan yang lalu dan adanya perang harga di pasar minyak.(Sari, dkk. 2021) Laju perekonomian Malaysia pada kuartal I 2020 mencapai 0,7\%. Pada kuartal II 2020 malaysia berada pada angka -17,1\%. Dan pada kuartal III 2020 Malaysia bisa mencatat kontraksi yang lebih rendah, yaitu $-2,7 \%$. Angka pada kuartal III 2020 Malaysia memiliki angka yang lebih baik dari angka pada kuartal II 2020.

4. Filipina

Sama seperti negara-negara lain Filipina memberlakukan pembatasan sosial/lockdown dan pembatalan penerbangan domestik dan internasional. Filipina merupakan negara yang tercatat mengalami penurunan ekonomi yang cukup besar. Penurunan laju perekonomian Filipina terjadi karena kebijakan pemerintah yaitu penerapan lockdown yang ketat di Filipina. Penerapan pembatasan sosial/lockdown dilakukan dengan ketat karena adanya ancaman dari Presiden Duterte yang akan memberlakukan darurat militer jika masyarakat Filipina tidak mengikuti aturan pembatasan sosial. Pulau Luzon menjadi pusat pembatasan sosial karena populasi manusia yang banyak dan Pulau Lozon merupan pusat perekonomian Filipina.(Yazid dan Jovita, 2020) Pada kuartal I 2020 ekonomi Filipina mengalami kontraksi, yaitu -0,2\%. Pada kuartal II 2020 mencapai -16,5\%. Tercatat pencapaian pada kuartal II 2020 merupakan yang terburuk. Pada kuartal II 2020 Filipina mengalami resesi karena sudah 2 kuartal yang berada pada angka minus. Pada kuartal III 2020 mencapai angka -11,5\%. Pemerintahan Filipina masih berusaha untuk memulihkan dan meningkatkan perekonomian Filipina.

5. Thailand

Thailand merupakan negara yang diprediksi akan mengalami resesi menyusul Singapura, karena laju perekonomian Thailand pada kuartal I 2020 sudah mencapai angka minus, yaitu 1,8\%. Pada kuartal II 2020 Thailand berkontraksi mencapai -12,2\%. Angka tersebut merupakan angka kontraksi terdalam bagi Thailand dari tahun 1998. Dan pada kuartal II 2020 Thailand sudah masuk resesi. Pada kuartal III 2020 Thailang masih diangka minus, yaitu $6,4 \%$. Penurunan laju perekonomian Thailand terjadi karena penurunan wisatawan asing yang datang ke Thailand dan karena terganggunya proses ekspor. Selain itu, mata uang bath naik lebih dari 6\%. Mata uang Bath menjadi mata uang yang berkinerja terbaik kedua di Asia sepanjang tahun 2020.(Nugroho, 2020)

6. Vietnam

Vietnam merupakan negara yang cukup kuat dalam menghadapi pandemi covid-19 ini. Pertumbuhan ekonomi yang masih mencapai nilai positif membuat Vietnam tidak mengalami kejadian resesi. Pada pertumbuhan ekonomi kuartal I/2020 mencapai angka 3,8\%. Pada kuartal II/2020 mencapai $0,4 \%$. Walaupun pada kuartal II/2020 mengalami penurunan dan pada kuartal II/2020 merupakan pertumbuhan ekonomi terburuk Vietnam selama 35 tahun belakang tetapi pertumbuhan ekonomi Vietnam tidak mencapai minus.(Asmara, 2020) Dan pada kuartal III/2020 Vietnam mengalami pertumbuhan kembali mencapai angka 2,62\%. Kestabilan pertumbuhan ekonomi di Vietnam dipengaruhi oleh kasus positif virus corona yang sedikit. Sampai tanggal 6 Februari 2021 kasus terinfeksi virus corona di Vietnam baru 1.985 kasus 
dan 35 orang yang meninggal karena terinfeksi virus corona. Jumlah kasus postif virus corona di Vietnam dapat dikatakan sedikit jika dibandingkan dengan negara lain.

Berikut ini daftar pertumbuhan ekonomi negara ASEAN :

Tabel 3.1 : Pertumbuhan ekonomi negara ASEAN

\begin{tabular}{|l|c|c|c|c|}
\hline \multicolumn{1}{|c|}{ Negara } & $\begin{array}{c}\text { Kuartal I } \\
\mathbf{2 0 2 0}\end{array}$ & $\begin{array}{c}\text { Kuartal II } \\
\mathbf{2 0 2 0}\end{array}$ & $\begin{array}{c}\text { Kuartal III } \\
\mathbf{2 0 2 0}\end{array}$ & Keterangan \\
\hline Indonesia & $2,97 \%$ & $-5,32 \%$ & $-3,49 \%$ & Resesi \\
\hline Singapura & $0,7 \%$ & $-42,9 \%$ & $-5,8 \%$ & Resesi \\
\hline Malaysia & $0,7 \%$ & $-17,1 \%$ & $-2,7 \%$ & Resesi \\
\hline Filipina & $0,2 \%$ & $-16.5 \%$ & $-11,5 \%$ & Resesi \\
\hline Thailand & $-1,8 \%$ & $-12,2 \%$ & $-6,4 \%$ & Resesi \\
\hline Vietnam & $3,8 \%$ & $0,4 \%$ & $2,62 \%$ & Tidak Resesi \\
\hline
\end{tabular}

Dari tabel diatas, menunjukan lebih banyak negara yang mengalami resesi selama pandemi virus corona. Negara yang mengalami resesi akan merasakan dampak dari terjadinya resesi. Dampak resesi akan tergantung pada lama berlangsungnya resesi dan tingkat penurunan output secara nasional. Semakin lama resesi, bisa jadi dampak yang ditimbulkan akan semakin mengerikan. Sebaliknya, jika otoritas suatu negara mampu segera mengatasi resesi yang terjadi, maka dampak buruk dari terjadinya resesi tersebut dapat diminimalisir. Dampak dari terjadinya resesi, antara lain:

1. Dampak Resesi Ekonomi pada Pemerintah

a) Jumlah Pengangguran Meningkat

Saat terjadi resesi, perusahaan akan terkena dampaknya. Perusahaan akan mengurangi karyawan atau pemutusan hubungan kerja (PHK) ketika pendapatan penjualan dan laba mengalami penurunan yang drastis. Terjadinya pengurangan karyawan merupakan suatu upaya perusahaan untuk meminimalisir biaya dan meningkatkan laba. Dan saat terjadi resesi perusahaan akan melakukan penundaan rekruitmen karyawan baru, sehingga semakin tinggi tingkat pengangguran di negara yang mengalami resesi. Pemerintah dituntut mampu mengatasi keadaan dan menemukan solusi untuk mengakhiri resesi supaya lapangan kerja dapat terbuka kembali. (NN, 2020)

b) Pinjaman Pemerintah Melonjak Tinggi

Pemerintah disetiap negara pasti membutuhkan dana untuk membiayai kebutuhan yang berkaitan dengan upaya pembangunan negara. Saat terjadi resesi pendapatan negara akan mengalami penurunan, disisi lain pemerintah tetap harus melakukan pembangunan diberbagai sektor termasuk menjamin kesejahteraan masyarakatnya. Hal ini menyebabkan defisit anggaran dan semakin besarnya total utang pemerintah. (NN, 2020)

c) Harga Aset Menurun

Saat pandemi virus corona ini, resesi global terjadi sehingga pasar internasional umumnya mengalami penurunan. Hal ini dipicu menurunnya tingkat permintaan konsumen. Contohnya selama pandemi virus corona, harga minyak dunia mengalami penurunan yang drastis akibat dari permintaan konsumen yang menurun. (NN, 2020)

d) Imbal Hasil Obligasi Menurun

Ketika terjadi resesi, umumnya imbal hasil obligasi pemerintah menurun. Di kala resesi, tabungan cenderung mengalami peningkatan dan pasar menuntut keamanan obligasi dibandingkan saham. Kekhawatiran nyata dari pasar tentang jatuhnya ekonomi disuatu negara yang mengancam finansial negara, dimana resesi akan menyebabkan pemerintah kekurangan likuiditas. (NN, 2020)

2. Dampak Resesi pada Perusahaan

a) Penurunan Pendapatan 
Selama resesi banyak bisnis yang mengalami kegagalan. Hal tersebut dipicu oleh banyak faktor, seperti goncangan ekonomi negatif, tergerusnya sumber daya riil, krisis kredit, jatuhnya harga aset berbasis utang, dan lainnya. Ketika bisnis gagal, jelas perusahaan mengalami penurunan pendapatan secara drastis. Sehingga perusahaan tentu saja akan mengambil kebijakan untuk mengamankan finansialnya. Kebijakan yang sering kali diambil adalah mengurangi jumlah pekerja dan menurunkan upah pekerja. Hal ini menyebabkan pendapatan menurun. Ketika pendapatan menurun, daya beli pun menurun. Masyarakat yang terkena PHK dan penurunan upah tersebut akan sulit untuk memenuhi kebutuhannya. Di saat daya beli masyarakat menurun, potensi perusahaan untuk meningkatkan pendapatan dari hasil penjualan produk atau jasa yang diproduksinya pun semakin kecil. Kondisi inilah yang ditakutkan perusahaan, karena mengancam kelancaran arus kasnya. (NN, 2020)

b) Turunnya Permintaan

Ketika resesi, masyarakat akan lebih berhati-hati dalam menggunakan atau membelanjakan uangnya. Hal ini mengakibatkan tingkat permintaan terhadap barang dan jasa mengalami penurunan. Jika permintaan menurun, maka perusahaan akan mendapatkan laba yang lebih rendah. Bahkan apabila permintaan tidak ada sama sekali, maka perusahaan berisiko mengalami kerugian dan tidak tertutup kemungkinan akan bangkrut. Ancaman dari terjadinya resesi ini untuk seluruh perusahaan yang ada di setiap industri atau sektor ekonomi. Keterbatasan modal dan aset yang dimiliki serta ketidakmampuan untuk memperoleh pinjaman guna mempertahankan operasional bisnis, memaksa mereka untuk keluar dari bisnis. (NN, 2020)

c) Perang Harga

Resesi memang mengancam perusahaan diberbagai industri. Saat resesi ini keadaan antar perusahaan seperti sedang perang, bagi yang memiliki cadangan modal dan aset lebih besar, peluang untuk bertahan dan keluar dari resesi lebih besar, meski harus mengalami kerugian sementara. Agar tetap survive, perusahaan-perusahaan yang mampu bertahan di tengah-tengah gempuran resesi cenderung mengambil langkah strategis, di antaranya adalah perang harga. Dalam perang harga, perusahaan sering berusaha menggantungkan diri pada pangsa pasar. Hal ini mengarah pada pemotongan harga yang agresif untuk menarik minat beli konsumen, meski harus berakibat pada berkurangnya profitabilitas. Profitabilitas yang berkurang memaksa perusahaan untuk melakukan efisiensi dengan memotong biaya operasional dan menutup area bisnis yang tidak menguntungkan. Dalam upaya pemotongan biaya ini, tak jarang perusahaan juga menurunkan upah pekerja, bahkan memberhentikan pekerja yang tidak terlibat dalam bisnis inti perusahaan. (NN, 2020)

3. Dampak Resesi pada Pekerja

Dampak nyata terjadinya resesi pada pekerja adalah pemutusan hubungan kerja (PHK), sehingga memaksa mereka menjadi pengangguran. Tingginya tingkat pengangguran berisiko memberikan dampak negatif yang dapat bertahan lama. Pada kehidupan sehari-hari, para pengangguran tersebut dituntut untuk tetap memenuhi kebutuhan baik dirinya pribadi maupun keluarganya. Masalah pengangguran tak hanya menimbulkan dampak ekonomi saja, tetapi juga sosial. Daerah dengan tingkat pengangguran tinggi cenderung mengalami lebih banyak masalah sosial. Tingkat pengangguran yang tinggi menjadi faktor penyebab terciptanya ketidakstabilan sosial, yang mengarah pada kerusuhan dan vandalisme. Bahkan, pengangguran massal dapat mengancam tatanan sosial dalam kehidupan berbangsa dan bernegara. (NN, 2020)

\subsubsection{Faktor yang membuat perekonomian menurun setelah adanya Covid-19}

Pandemi virus corona membuat perekonomian mengalami penurunan. Beberapa negara harus mengalami kondisi resesi, hal tersebut terjadi karena dampak dari pandemi ini yang 1 tahun lalu 
muncul di Wuhan, China. Virus corona masuk ke Indonesia pada bulan Maret 2020. Dari hadirnya virus corona di Indonesia membuat kehidupan masyarakat berubah. Masyarakat harus terbiasa dengan kebiasaan baru agar terhindar dari virus corona. Penyebaran virus corona yang cepat dan mudah menginfeksi manusia membuat pemerintah membuat kebijakan yang mengakibatkan aktivitas perekonomian menjadi terhambat dan perekonomian negara menjadi turun. Dari beberapa negara yang penulis sudah bahas dapat diambil beberapa faktor yang mengakibatkan terjadinya penurunan laju ekonomi di negara-negara ASEAN. Faktor pertama, yang menyebabkan beberapa negara mengalami penurunan laju perekonomian, yaitu karena dampak dari kebijakankebijakan yang pemerintah laksanakan. Seperti di Malaysia dan Filipina, negara tersebut terjadi penurunan laju perekonomian karena kebijakan pemerintah yang melakukan kebijakan lockdown. Di Indonesia pun kegiatan perekonomian melambat karena kebijakan social distancing. Kebijakan yang melarang masyarakan membuat kerumunan. Kebijakan Work From Home yang mengakibatkan banyak perusahaan yang mengalami kerugian dan melakukan PHK pada karyawannya. Dan karena kebijakan sosial distancing, work from home, pembelajaran jarak jauh, sampai PSBB membuat jumlah konsumsi masyarakat menjadi menurun dengan drastis yang membuat laju perekonomian mendorong ke angka negatif. Seperti di Singapura pun sama permintaan domestik mengalami penurunan membuat laju perekonomian Singapura pun menurun.

Faktor kedua yang mengakibatkan terjadinya penurunan laju perekonomian, yaitu karena berkurangnya wisatawan yang datang ke negara tersebut. Seperti di Indonesia dari sektor Pariwisata mengalami penurunan yang sangat drastis selama pandemi virus corona. Begitupun di Thailand, negara Thailand sampai mengalami resesi karena berkurangnya wisatawan yang datang. Faktor ketiga, terhambatnya proses ekspor dan impor mengakibatkan proses produksi menjadi terhambat dan sektor bisnis jadi terganggu. Faktor keempat, berkurang dan tertundanya kegiatan investasi dapat memberi pengaruh bagi laju pertumbuhan perekonomian. Karena faktor-faktor tersebut beberapa negara mengalami penurunan perekonomian selama pandemi, sehingga negaranegara tersebut harus mengalami resesi. Resesi merupakan perlambatan laju pertumbuhan ekonomi bernilai negatif selama 2 kuartal atau lebih.(Wikipedia, 2020) Faktor terjadinya resesi, yaitu:

1. Guncangan Ekonomi Secara Tiba-tiba

Guncangan ekonomi secara tiba-tiba maksudnya ialah masalah yang tiba-tiba hadir sehingga menimbulkan kerusakan finansial. Seperti saat pandemi virus corona ini yang membuat perekonomian di dunia terhambat.(Freycinetia dan Ramadhansari, 2020)

2. Hutang yang Berlebihan

Memiliki hutang yang berlebihan dapat dengan mudah membalikkan perekonomian, karena biaya pembayaran hutang akan meningkat(berbunga) sampai titik kita tidak mampu membayarnya tagihan dan akan mengalami kebangrutan.(Freycinetia dan Ramadhansari, 2020)

3. Gelembung Aset

Perekonomian akan mengalami resesi jika para investor terlalu optimis jika perekonomian kuat dan mulai menggembungkan pasar saham. Ketika gelembung itu meletus, panic selling dapat menghancurkan perekonomian.(Freycinetia dan Ramadhansari, 2020)

4. Inflasi Terlalu Tinggi

Inflasi merupakan tren harga yang stabil dan naik dari waktu ke waktu. Inflasi bukan suatu hal yang buruk, akan tetapi jika inflasi berlebihan akan menjadi bahaya. Perekonomian akan melemah karena hancurnya daya beli dan konsumsi.(Freycinetia dan Ramadhansari, 2020)

5. Deflasi Berlebihan

Deflasi adalah saat harga turun dari waktu ke waktu. Menyebabkan upah menyusut lalu menekan harga. Ketika umpan balik deflasi lepas kendali, orang akan berhenti mengeluarkan 
uang sehingga merusaknya perekonomian yang dapat menyebabkan resesi.(Freycinetia dan Ramadhansari, 2020)

6. Perubahan Teknologi

Teknologi memang meningkatkan produktivitas dan membantu perekonomian dalam jangka panjang. Tetapi perubahan teknologi juga dapat menyebabkan resesi, seperti revolusi industri membuat beberapa SDM tidak digunakan kembali beralih pada teknologi yang menyebabkan bertambahnya pengangguran.(Freycinetia dan Ramadhansari, 2020)

\section{KESIMPULAN}

Berdasarkan hasil penelitian, penulis dapat menyimpulkan bahwa dampak dari pandemi virus corona tidak hanya pada sektor kesehatan, tetapi semua sektor juga merasakan dampaknya. Salah satunya, sektor ekonomi dan bisnis. Pertumbuhan ekonomi global dipastikan mengalami kelambatan, termasuk negara yang bergabung dengan ASEAN. Beberapa negara yang bergabung dengan ASEAN harus mengalami resesi saat pandemi virus corona. Hal tersebut terjadi karena adanya kebijakan pemerintah disetiap negara yang mengharuskan masyarakat tidak membuat kerumunan dan mengurangi aktivitas di luar rumah yang menyebabkan proses perekonomian pun terhambat. Kebijakan tersebut dibuat agar penyebaran virus corona dapat teratasi dan pandemi cepat berakhir sehingga semua bisa melakukan aktivitas normal seperti dahulu.

\section{UCAPAN TERIMAKASIH}

Terimakasih kepada Sekolah Tinggi Ilmu Ekonomi Media Nusantara Citra

\section{DAFTAR PUSTAKA}

Asmara Chandra Gian. Semua Negara Ekonominya minus? Coba Cek Vietnam Bro! Diakses pada Februari, 08, 2021

Budiyanti Eka. Dampak Virus Corona Terhadap Sektor Perdagangan Dan Pariwisata Indonesia. Diakses pada November.

Dampak Resesi Ekonomi. Diakses pada Februari, 18, 2021

Freycinetia dan Ramadhania. Indonesia Resesi: Simak Definisi, Faktor Penyebab, dan Dampak ke Masyarakat. Diakses pada Januari, 27, 2020.

Gufman Hanif. Bagaimana COVID-19 Mengubah Ekonomi Indonesia \& ASEAN?. Diakses Januari, 20, 2021.

Hakim Iqbal. Pengertian Ekonomi Menurut Para Ahli. Diakses pada November, 02, 2020.

Hanoantubun Silpa. Dampak Covid - 19 terhadap Prekonomian Indonesia. Diakses pada November, 02, 2020.

Hidayat Anwar. METODE PENELITIAN: Pengertian, Tujuan, Jenis. Diakses pada November, 16, 2020. Ibrahim Abdul M. Dampak Covid-19 Terhadap Perekonomian dan Kebijakan Pemerintah Indonesia.

Informasi tentang virus corona. diakses pada November, 02, 2020

Joharudin Agus et.al. Panic Syndrom Covid-19 : Penekanan Terhadap Kebijakan Yang Diberikan. Diakses Januari, 25, 2021.

Kemkes. hindari lansia dari Covid-19, diakses pada November, 02, 2020

Mahardika Agus S. Studi Literatur adalah, diakses pada November, 16, 2020

Nugroho Aprianto Cahyo. Ekonomi Merosot 12,2 Persen pada Kuartal II/2020, Thailand Sah Resesi! Diakses pada Januari, 25, 2021.

Purwanto A. Strategi ASEAN Merespons Dampak Covid-19. Diakses pada November, 02, 2020.

Rizal Jawahir G. Pandemi Covid-19, Apa Saja Dampak pada Sektor Ketenagakerjaan Indonesia? Diakses Pada November, 02, 2020.

Sandi, Ferry. 2020. Pemerintah Klaim Baru 2,1 Juta Pekerja Kena PHK-Dirumahkan. Diakses pada tanggal 8 Februari 2021 
Setyawati Natalia. Implementasi Sanksi Pidana Bagi Masyarakat Yang Beraktivitas Di Luar Rumah Saat Terjadinya Pandemi Covid-19. Diakses pada Januari, 25, 2021.

Sina Peter Garlans. EKONOMI RUMAH TANGGA DI ERA PANDEMI COVID-19. Diakses pada Januari, 25, 2021.

Sirusa BPS. 2020. Daftar Istilah. Diakses pada tanggal 19 November 2020

Sofuroh, Faidah Umu. 2020. Data Kemenaker: Pekerja Terdampak COVID-19 Capai Sekitar 3 Juta Orang. Diakses pada tanggal 8 Februari 2021

Thomas, Vincent Fabian. 2020. Angka Pengangguran 2020 Terburuk, Apa yang Bisa Dilakukan Jokowi? Diakses pada tanggal 26 Oktober 2020

Wikipedia. Ilmu Ekonomi, diakses pada November, 02, 2020

Wikipedia. Metodologi, diakses pada November, 16, 2020

Wikipedia. Perhimpunan Bangsa-Bangsa Asia Tenggara, diakses pada November, 02, 2020

Wikipedia. Resesi, diakses Januari, 27, 2021 dari https://id.wikipedia.org/wiki/Resesi

Wuryandani Dewi. Dampak Pandemi Covid-19 Terhadap Pertumbuhan Ekonomi Indonesia 2020 Dan Solusinya. Diakses Januari, 20, 2021

Yazid dan Jovita. Dampak Pandemi Terhadap Mobilitas Manusia di Asia Tenggara. Diakses Januari, 25, 2021. Rizal, Jawahir Gustav. 2020. Pandemi COVID-19, Apa Saja Dampak pada Sektor Ketenagakerjaan Indonesia? Diakses pada tanggal 26 Oktober 2020 